\title{
The silver of the South Iberian El Argar Culture: A first look at production and distribution
}

\author{
La plata de la Cultura de El Argar del Sur de la Península Ibérica: una primera \\ aproximación a su producción y distribución
}

\author{
Martin Bartelheim (*) \\ Francisco Contreras Cortés $(* *)$ \\ Auxilio Moreno Onorato (**) \\ Mercedes Murillo-Barroso (***) \\ Ernst Pernicka $(*)$
}

\begin{abstract}
More than 700 silver objects are known from the Middle Bronze Age El Argar culture, which contrasts significantly with the rest of Bronze Age Europe, where silver is mostly rare. This has traditionally been explained by the difficulties of extracting silver from complex ores by cupellation and the relative abundance of easily accessible occurrences of native silver and silver chlorides in the south of the Iberian peninsula. However, until now in the Iberian Bronze Age the use of native silver has only been inferred by the absence of evidence of cupellation. The results of trace element analysis of a series of silver objects from several Argaric settlements reveal for the first time positive evidence for the use of native silver. Lead isotope analyses show that hardly any of the objects were made of silver from known and characterised mining districts.
\end{abstract}

\section{RESUMEN}

Se han documentado más de 700 objetos de plata de la cultura argárica del Bronce Medio. Esta cifra contrasta con la realidad del II milenio AC europeo, donde la

(*) Institut für Ur- und Frühgeschichte und Archäologie des Mittelalters, University of Tübingen. Schloss Hohentübingen. D 72070 Tübingen. Germany.

E-mail: martin.bartelheim@uni-tuebingen.de;ernst.pernicka@ cez-archaeometrie.de

(**) Dpto. de Prehistoria y Arqueología, Universidad de Granada. Campus Universitario de Cartuja s/n. 18071 Granada. Spain.E-mail: fccortes@ugr.es; auxiliomoreno@ugr.es

(***) Instituto de Historia, CCHS-CSIC. C/ Albasanz 26-28. 28027 Madrid. Spain. E-mail: mercedes.murillo@cchs.csic.es

Received: 28-XII-2011; accepted: 30-IV-2012. plata es muy escasa. Esto se ha explicado tradicionalmente por la dificultad de extraer plata de minerales complejos mediante la técnica de copelación y la relativa abundancia de plata nativa y cloruros de plata fácilmente accesibles en el sur de la Península Ibérica. Sin embargo, hasta ahora, el uso de plata nativa en la Edad del Bronce ibérica se había deducido principalmente por la falta de evidencias de copelación. Los resultados de los análisis de elementos traza de una serie de objetos de plata de varios yacimientos argáricos suministran por primera vez una evidencia positiva del uso de plata nativa. Los análisis de isótopos de plomo demuestran que la mayoría de los objetos no procede de ninguno de los distritos mineros conocidos y caracterizados.

Key words: Bronze Age; Argar; Silver; Lead Isotope Analysis; Trace Elements; Provenance.

Palabras clave: Edad del Bronce; Argar; Plata; Isótopos de Plomo; Elementos traza; Procedencia.

\section{INTRODUCTION}

In prehistoric Europe, silver is a rare precious metal compared to gold. It has been known on the continent since the $4^{\text {th }}$ millennium BC (Briard 1980; Hásek 1989; Makkay 1991; Primas 1995, 1996; Hansen 2009), but it appears only sporadically in the archaeological record from periods before the advent of the Romans. The scarcity of silver objects in prehistoric Europe is remarkable in view of the large amounts of technically sophisticated products made of other metals like copper, bronze, gold or iron. In the Ancient Near 
East, in the Caucasus area and in the eastern Mediterranean silver is quite abundant since the $4^{\text {th }} / 3^{\text {rd }}$ millennia BC (Prag 1978; Pernicka 1990, 56-59; Leskov 2008; Hansen 2009). Also in the Aegean it is well represented in the archaeological record from the $3^{\text {rd }}$ millennium onwards (Renfrew 1967; Wagner and Weisgerber 1985; Pernicka 1990: 108-110). The same goes for lead objects which are also rare in European prehistory. In the Ancient Near East and the eastern Mediterranean, after a period of use of native silver, silver was produced more and more from lead ores via cupellation. For this we have secure evidence from the $4^{\text {th }}$ millennium in the shape of production debris - e.g. pieces of litharge from a Late Uruk context in Habuba Kabira, Syria (Kohlmeyer 1990; Pernicka 1990: 58). However, in prehistoric Europe evidence of knowledge of this quite complex two-step production process (Bachmann 1990) has not been found yet. It seems as if until the $1^{\text {st }}$ millennium this knowledge did not transcend the Aegean towards the north and the west. Even afterwards it advanced only slowly.

\section{INVESTIGATION INTO PREHISTORIC SILVER METALLURGY ON THE IBERIAN PENINSULA}

In the south of the Iberian peninsula the situation is different. Especially from the Middle Bronze Age El Argar culture (first half of the $2^{\text {nd }}$ millennium BC) in the Iberian southeast exceptionally many silver objects are known (Fig. 1): Until now more than 700 pieces have been pub-

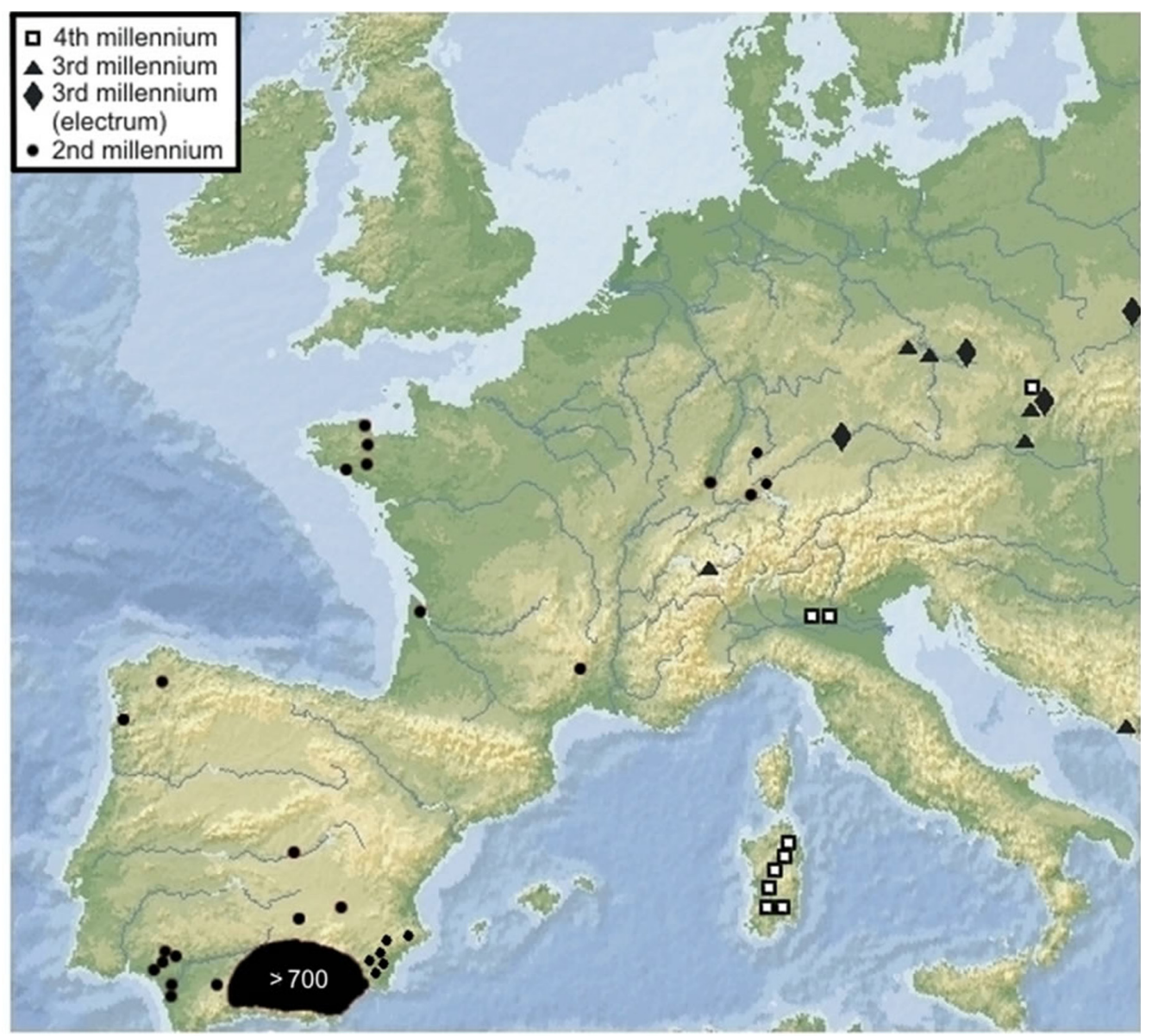

Fig. 1. Distribution of prehistoric $\left(4^{\text {th }}-2^{\text {nd }}\right.$ mill. BC) silver in western and central Europe. The black area in southern Iberia marks the second millennium find concentration. 
lished (Montero et al. 1995; Simón 1998; Pingel et al. 2003; Bartelheim 2007: Liste 2; Aranda et al. 2008). They are mostly ornaments, usually small rings or spirals, but also some massive bracelets, beads, diadems or rivets on bronze daggers have been found.

Research into prehistoric silver has generally played only a minor role in archaeometallurgy on the Iberian peninsula (exceptions: Montero et al. 1995; Hunt 1998), since it focussed mainly on copper/bronze (Junghans et al. 1960, 1968, 1974; Rothenberg and Blanco 1981; Montero 1994; Delibes and Montero 1999) and gold (Hartmann 1970, 1982; Perea 1991; Pingel 1992; Perea et al. 2010). During the past decades the analytical basis of research into archaeometallurgy on the Iberian peninsula has made a lot of progress. A large number of XRF analyses have been carried out on Bronze Age metal objects -mainly copper and bronze but also silver (Rovira et al. 1997)- as well as to a smaller extent lead isotope analyses on Bronze Age metals (Stos-Gale et al. 1999; Hunt 2003). This has been complemented by several series of geological lead isotope analyses of ore bodies (see below).

On the Iberian peninsula evidence for cupellation has been found securely dated for the first time in the context of the Phoenician colonisation in the $1^{\text {st }}$ millennium BC (Pérez Macías 1996; Hunt 1998, 2003; Bartelheim 2007). By that time the vast ore resources in the hinterland of the south-west Andalusian coast were exploited to a large scale. According to ancient authors (e.g. Herodotus, Histories IV, 152; Diodorus V, $35,4-5)$ the smelted silver was transported via Phoenician harbours to the colonists' Levantine mother cities. The production process of the prePhoenician Bronze Age silver objects has been matter of intense discussions for a long time. The pioneer investigators of the El Argar culture, $\mathrm{H}$. and L. Siret -who mainly worked as mining engineers in the south-east Spanish silver mine of Herrerías - recognised already at the end of the $19^{\text {th }}$ century the potential of their ore deposit for the early production of silver. This was mainly due to the abundant appearance of native silver. They already carried out chemical analyses on silver objects from their excavations too, which revealed only low amounts of lead. Since the presence of lead in silver was considered to be a clear indicator of the cupellation process and because of the observation that in Bronze Age con- texts, production residues of cupellation were never reported, they concluded that the silver of the El Argar culture was originated from deposits of native silver or of horn silver/cerargyrite (silver chloride) which can be processed relatively easy (Siret and Siret 1887). The Herrerías silver ore deposit as a major source of native silver (Montero et al. 1995: 103) is likely to have played a special role in Bronze Age silver production. This is also suggested by the very high concentration of silver objects in the surrounding Vera basin -the core region of the El Argar culturewith settlements like El Argar in which 276 pieces were found, El Oficio (45 pieces) or Fuente Alamo (68 pieces) (Montero 1994: 122-134; Pingel et al. 2003) (Fig. 2).

The ideas of the Sirets concerning El Argar silver production are widely accepted (cf. Montero 1994; Montero et al. 1995; Gómez Ramos 1999; Hunt 2003). Nevertheless it has been so far based only on negative evidence: lack of higher $(\geq 0.1 \%)$ lead contents in Bronze Age silver higher values would point towards cupellationand the absence of cupellation residues in the archaeological record. A few dissenting opinions argued for the existence of pre-Phoenician Bronze Age cupellation on the Iberian peninsula because trace element analyses of some Bronze Age silver objects showed higher lead contents (Harrison 1983) or because some Bronze Age slags were considered to have a composition typical for silver production (Pérez Macías and Frías 1989; Pérez Macías 1996). Since the origin of the corresponding technological knowledge remained unclear, it was pleaded for a local development or a technology transfer from the eastern Mediterranean already in the pre-colonial Bronze Age in the course of sporadic trans-Mediterranean contacts (Gómez Ramos 1999: 187). However, until now it has not been possible to retrieve more finds than the ones mentioned before which could confirm the existence of pre-Phoenician cupellation on the Iberian peninsula.

It has often been stressed that it is not always possible to make an exact distinction between cupelled silver and that of a different origin (native silver or horn silver) only on the basis of the lead content of the final product. However, native silver can contain up to $0.1 \%$ lead and horn silver up to $10 \%$ (Patterson 1971: 304,315 ). It is also possible that mixed ores were smelted while processing horn silver which often appears in para- 


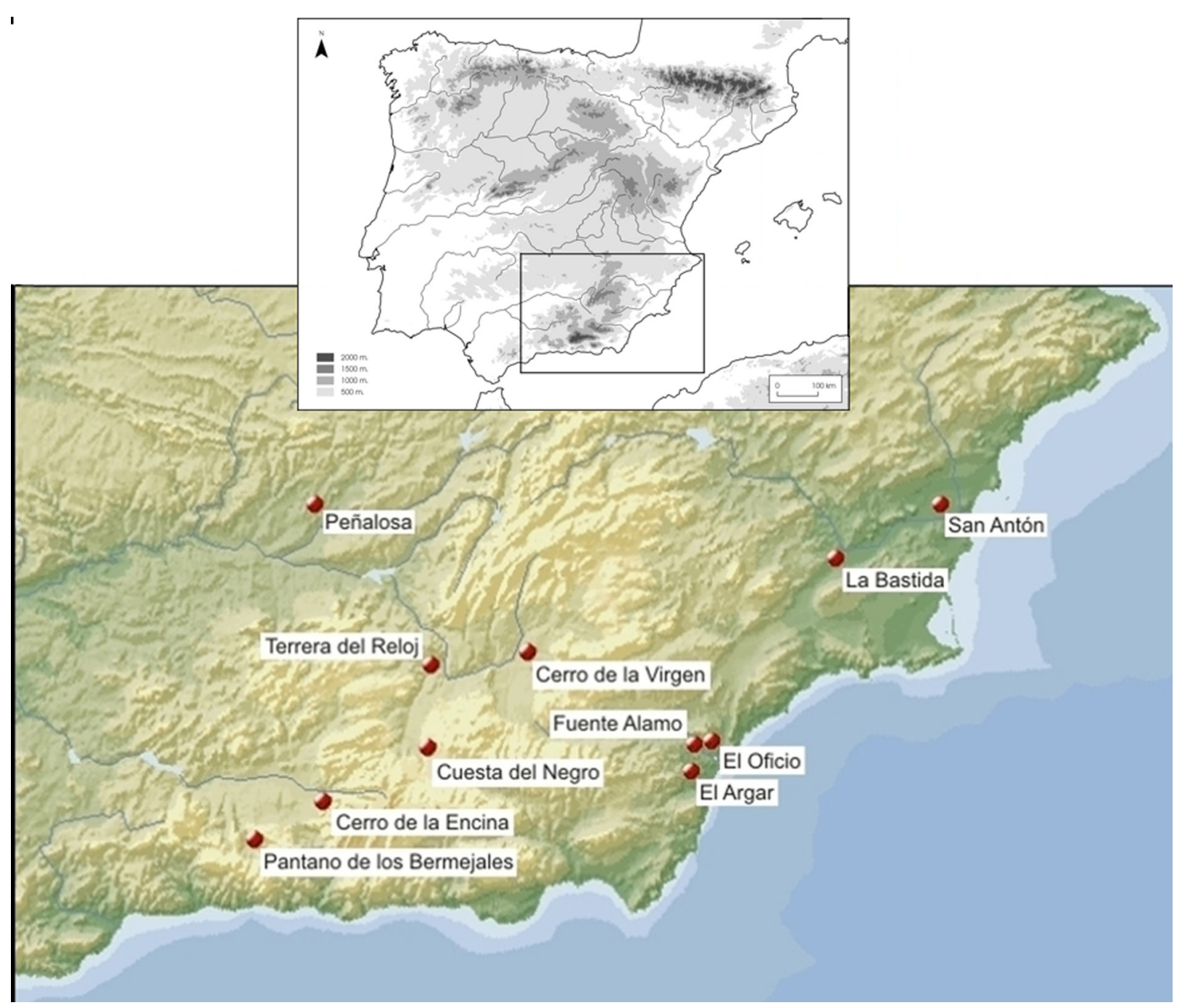

Fig. 2. Map of the archaeological sites mentioned in the text.

genesis with lead ores (Arribas et al. 1989: 78; Montero et al. 1995: 100-101).

How else can cupelled silver be distinguished from silver produced from rich silver ores without lead being the first smelting product? In $1971 \mathrm{C}$. Patterson pointed out that native silver usually is not entirely pure, but contains trace elements like $\mathrm{Hg}, \mathrm{Cu}, \mathrm{As}$ and $\mathrm{Sb}$ (Patterson 1971: 301). These should be detected also in products made of native silver, as long as they have not gone through pyrotechnical treatment during production. However, in the cupellation process most of the trace elements in the lead are almost completely removed while typically a few permill of lead re- main in the silver (Pernicka and Bachmann 1983; Pernicka 1987: 641). Therefore low contents of lead together with volatile and/or easily oxidized elements, e.g. of $\mathrm{Hg}, \mathrm{Cu}, \mathrm{As}$, and $\mathrm{Sb}$ (also $\mathrm{Co}, \mathrm{Ni}$, $\mathrm{Bi}, \mathrm{Sn}, \mathrm{Zn}, \mathrm{U})$ are diagnostic for native silver and high lead contents without any further impurities except for $\mathrm{Au}, \mathrm{Cu}$, and $\mathrm{Bi}$ are characteristic for cupelled silver (Pernicka 1987: 641; Hunt 2003: 346). In the past it has been impossible to identify these important markers for native silver in the analysed objects since compositional analyses of prehistoric silver were mostly carried out by emission spectroscopy or X-ray fluorescence (XRF) with relatively high detection limits $(0.05 \%)$. 


\section{COMPOSITIONAL ANALYSES OF SILVER OBJECTS FROM EL ARGAR CULTURE SETTLEMENTS}

A series of 16 silver objects (wire rings, spirals, a bracelet and rivets of two bronze daggers, cf. Fig. 3) from recent excavations of El Argar culture sites was analysed for trace elements with EDXRF and lead isotopes using a MC-ICP-MS spectrometer at the Curt Engelhorn Centre for Archaeometry in Mannheim.

\subsection{Results and Discussion}

Trace element concentrations are presented in table 1. Apart from silver as the major component the objects contain a few impurities, whereas the high $\mathrm{Cu}$ values of MA-081332, 1335, 1340 and 1344 could indicate intentional alloying. However, the trace element patterns of those four samples do not differ significantly from the ones of pure silver, as can be seen in the principal component analysis (Fig. 4). According to cluster analysis, four groups can be identified in spite of the small population. Bi has been excluded both

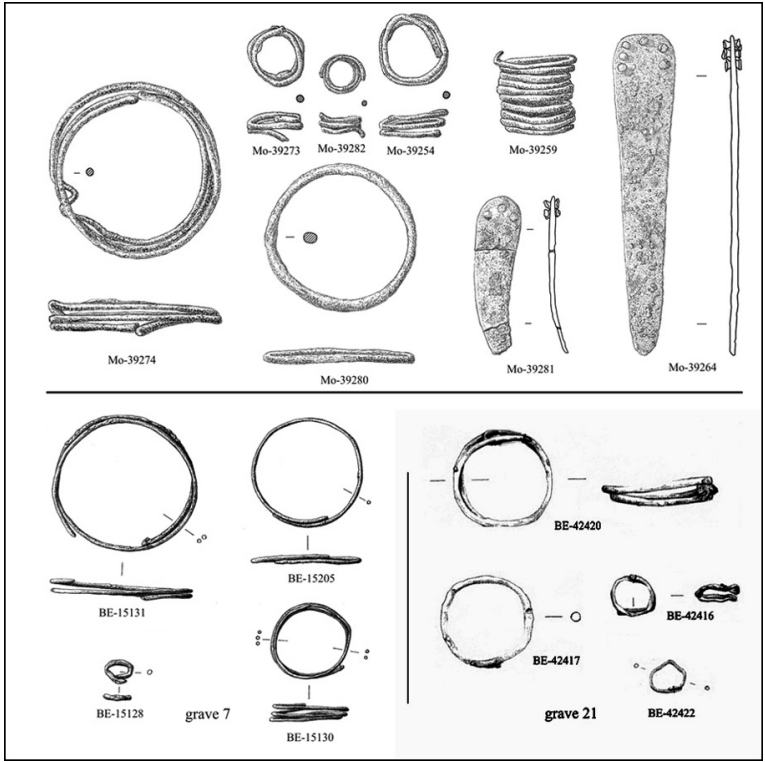

Fig. 3. Analysed silver objects from the El Argar culture settlements of Cerro de la Encina (Monachil, Granada) (grave 21) (top) and Peñalosa (Baños de la Encina, Jaén) (graves 7 and 21) (bottom).

\begin{tabular}{|l|l|l|l|l|r|r|c|c|c|c|}
\hline & & \multicolumn{1}{|c|}{$\mathbf{C u}$} & $\mathbf{Z n}$ & $\mathbf{A g}$ & $\mathbf{C d}$ & $\mathbf{S n}$ & $\mathbf{A u}$ & $\mathbf{H g}$ & $\mathbf{P b}$ & $\mathbf{B i}$ \\
\cline { 3 - 11 } Analysis no. & Sample no. & $\mathbf{\%}$ & $\mathbf{\%}$ & $\mathbf{\%}$ & $\mathbf{\%}$ & $\mathbf{\%}$ & $\mathbf{\%}$ & $\mathbf{\%}$ & $\mathbf{\%}$ & $\mathbf{\%}$ \\
\hline MA-081330 & BE-15128 & 0.45 & 0.12 & 99 & 0.01 & 0.05 & 0.07 & 0.09 & 0.06 & $<0.01$ \\
MA-081331 & BE-15130 & 0.71 & 0.29 & 99 & 0.03 & 0.11 & 0.10 & 0.02 & 0.01 & 0.01 \\
MA-081332 & BE-15131 & 4.9 & 0.33 & 94 & 0.01 & 0.01 & 0.02 & 0.24 & 0.07 & $<0.01$ \\
MA-081333 & BE-15205 & 0.72 & 0.19 & 99 & 0.02 & 0.05 & 0.09 & 0.01 & 0.01 & 0.01 \\
MA-081334 & BE-42416 & 0.20 & 0.28 & 99 & 0.01 & $<0.01$ & 0.06 & 0.23 & 0.09 & $<0.01$ \\
MA-081335 & BE-42417 & 8.9 & 0.19 & 91 & $<0.01$ & 0.03 & 0.25 & 0.04 & 0.03 & $<0.01$ \\
MA-081336 & BE-42420 & 0.64 & 0.17 & 99 & 0.01 & $<0.01$ & 0.31 & 0.03 & 0.02 & $<0.01$ \\
MA-081337 & BE-42422 & 0.08 & 0.17 & 99 & 0.06 & 0.11 & 0.09 & 0.12 & 0.07 & $<0.01$ \\
MA-081338 & Mo-39254 & 0.27 & 0.15 & 99 & 0.05 & 0.02 & 0.16 & 0.08 & 0.04 & $<0.01$ \\
MA-081339 & Mo-39259 & 0.41 & 0.56 & 98 & 0.02 & 0.11 & 0.36 & 0.14 & 0.03 & $<0.01$ \\
MA-081340 & Mo-39264 & 7.81 & 0.06 & 92 & $<0.01$ & 0.03 & 0.06 & 0.04 & 0.09 & $<0.01$ \\
MA-081341 & Mo-39273 & 0.26 & 0.35 & 99 & 0.06 & 0.02 & 0.08 & 0.30 & 0.17 & $<0.01$ \\
MA-081342 & Mo-39274 & 0.98 & 0.03 & 99 & $<0.01$ & 0.02 & 0.05 & 0.02 & 0.01 & $<0.01$ \\
MA-081343 & Mo-39280 & 2.3 & 0.02 & 97 & 0.03 & 0.01 & 0.08 & 0.01 & 0.01 & $<0.01$ \\
MA-081344 & Mo-39281 & 24 & 0.06 & 75 & $<0.01$ & 0.06 & 0.10 & 0.04 & 0.05 & $<0.01$ \\
MA-081345 & Mo-39282 & 1.2 & 0.32 & 98 & 0.08 & 0.03 & 0.15 & 0.12 & 0.05 & $<0.01$ \\
\hline
\end{tabular}

Tab. 1. Results of EDXRF analyses of silver artefacts from the Argaric settlements of Cerro de la Encina (Monachil), prov. Granada (Mo) and Peñalosa, prov. Jaén (BE). Sb contents are below the detection limit of $0.01 \%$. Data are mean values of several normalized measurements. 


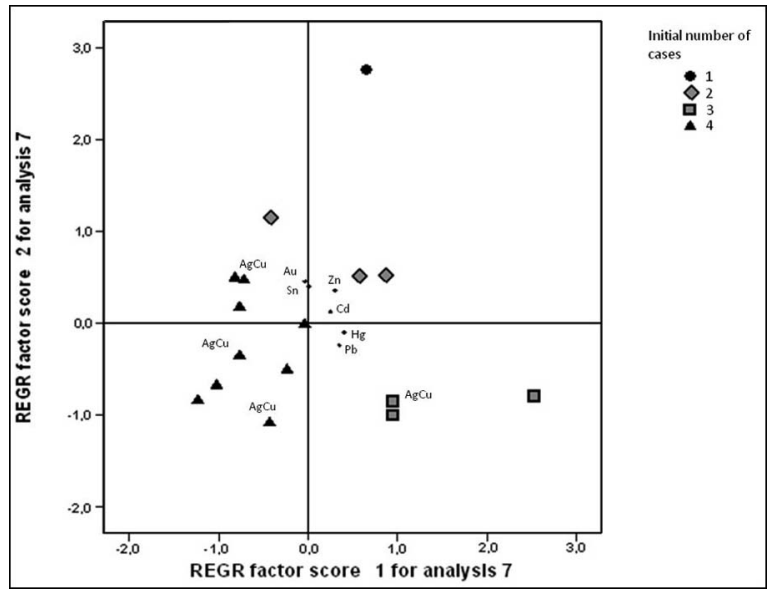

Fig. 4. Principal component analyses of EDXRF trace element analyses of the silver objects from Cerro de la Encina and Peñalosa (cf. Tab. 1).

in the cluster and factor analyses as this element is under the detection limit in most of the samples, except for two ones which both have $0.01 \%$ Bi. $\mathrm{Cd}$ and $\mathrm{Zn}$ have been included although their correlation coefficients are not highly significant (Cd has a coefficient of 0.241 with the first component and of 0.124 with the second component; and $\mathrm{Zn}$ has a coefficient of 0.395 with the first component and of 0.259 with the second one). For the other trace elements cluster analysis has been applied and four groups can be distinguished (Tab. 2 and Fig. 4). The first group contains only one sample which is richer in $\mathrm{Au}, \mathrm{Zn}$ and in minor quantity, also in $\mathrm{Sn}$. The second group is composed by three samples with higher values of $\mathrm{Sn}$ and $\mathrm{Cd}$. The third group is formed by three samples with high levels of $\mathrm{Hg}$ and $\mathrm{Pb}$, and the fourth group is composed by most of the samples where three of the four copper-silver samples are plotted. It can be seen that those $\mathrm{AgCu}$ samples do not form a different group, and if copper of different origin is added to silver it would be expected that some impurities were introduced into the alloy.

The four groups of the cluster analysis match with those of the principal component analysis and are plotted in figure 4, where the first component is defined by high levels of $\mathrm{Hg}$ and $\mathrm{Pb}$ and negative values of $\mathrm{Au}$ and up to a point $\mathrm{Sn}$, and the second component is defined by high levels of $\mathrm{Sn}$ and $\mathrm{Au}$ and low levels of $\mathrm{Hg}$ and $\mathrm{Pb}$ (Tab. 3).

In all cases $\mathrm{Pb}$ contents are low (apart from one all objects contain less than $0.1 \%$ ) and are combined with a marked presence of $\mathrm{Hg}, \mathrm{Sn}$ and $\mathrm{Cu}$ which, as discussed above, strongly suggests the use of native silver. By this it is possible to document directly the use of this material in the prehistory of the Iberian peninsula. In the same direction point the analytical results of two beads that were discovered in grave 111 in Fuente Álamo (Almería). According to SEM-EDX and XRD analyses they were made of native silver and cerargyrite (Pozo et al. 2004) which provides clear evidence for the use of both native silver and silver chlorides in the Argaric society. Moreover, those analyses reveal large variations in copper contents (from below detection limit to $17.9 \%$ wt copper). This could suggest that the copper measured in the artefacts could be due to copper associated with silver chlorides rather than the addition of metallic copper or copper ores of different origin which would have led to different impurity patterns.

\begin{tabular}{|l|c|c|c|c|}
\hline & \multicolumn{4}{|c|}{ Cluster } \\
\cline { 2 - 5 } & $\mathbf{1}$ & $\mathbf{2}$ & $\mathbf{3}$ & $\mathbf{4}$ \\
\hline ZScore(Sn) & 1.80 & 1.80 & -.56 & -1.08 \\
ZScore(Au) & 2.39 & -.38 & -.49 & 1.88 \\
ZScore(Hg) & .49 & .27 & 2.25 & -.72 \\
ZScore(Pb) & -.49 & .46 & 2.83 & -.76 \\
ZScore(Zn) & 2.47 & -.25 & 1.01 & -.25 \\
ZScore(Cd) & -.17 & 1.41 & 1.41 & -.57 \\
Number of cases & 1 & 3 & 3 & 9 \\
\hline
\end{tabular}

Tab. 2. Cluster analyses of silver artefacts from the Argaric settlements of Cerro de la Encina (Monachil), prov. Granada (Mo) and Peñalosa, prov. Jaén (BE) and number of cases in each group. 


\begin{tabular}{|c|c|c|}
\hline \multirow{2}{*}{} & \multicolumn{2}{|c|}{ Component } \\
\cline { 2 - 3 } & $\mathbf{1}$ & $\mathbf{2}$ \\
\hline $\mathrm{Sn}$ & .006 & .405 \\
$\mathrm{Au}$ & -.034 & .456 \\
$\mathrm{Hg}$ & .400 & -.093 \\
$\mathrm{~Pb}$ & .345 & -.237 \\
$\mathrm{Zn}$ & .295 & .359 \\
$\mathrm{Cd}$ & .241 & .124 \\
\hline
\end{tabular}

Tab. 3. Component Scores Coeficient Matrix. Extraction Method: Principal Component Analysis. Rotation Method: Quartimax with Kaiser Normalization.
Native silver is not an abundant resource in nature. Nevertheless, there are many mines with native silver in Iberia, especially in the south (Fig. 5), which could have produced enough metal to manufacture all known Bronze Age silver objects. Due to the conversion of silver into chlorides in reaction with water, it has been argued that native silver must occur below the hydrostatic level and hence, contrary to copper, it would have been hardly accessible to prehistoric societies (Tylecote 1987). In fact, native silver often occurs associated with silver chlorides such as horn silver or cerargyrite $(\mathrm{AgCl}$, Patterson

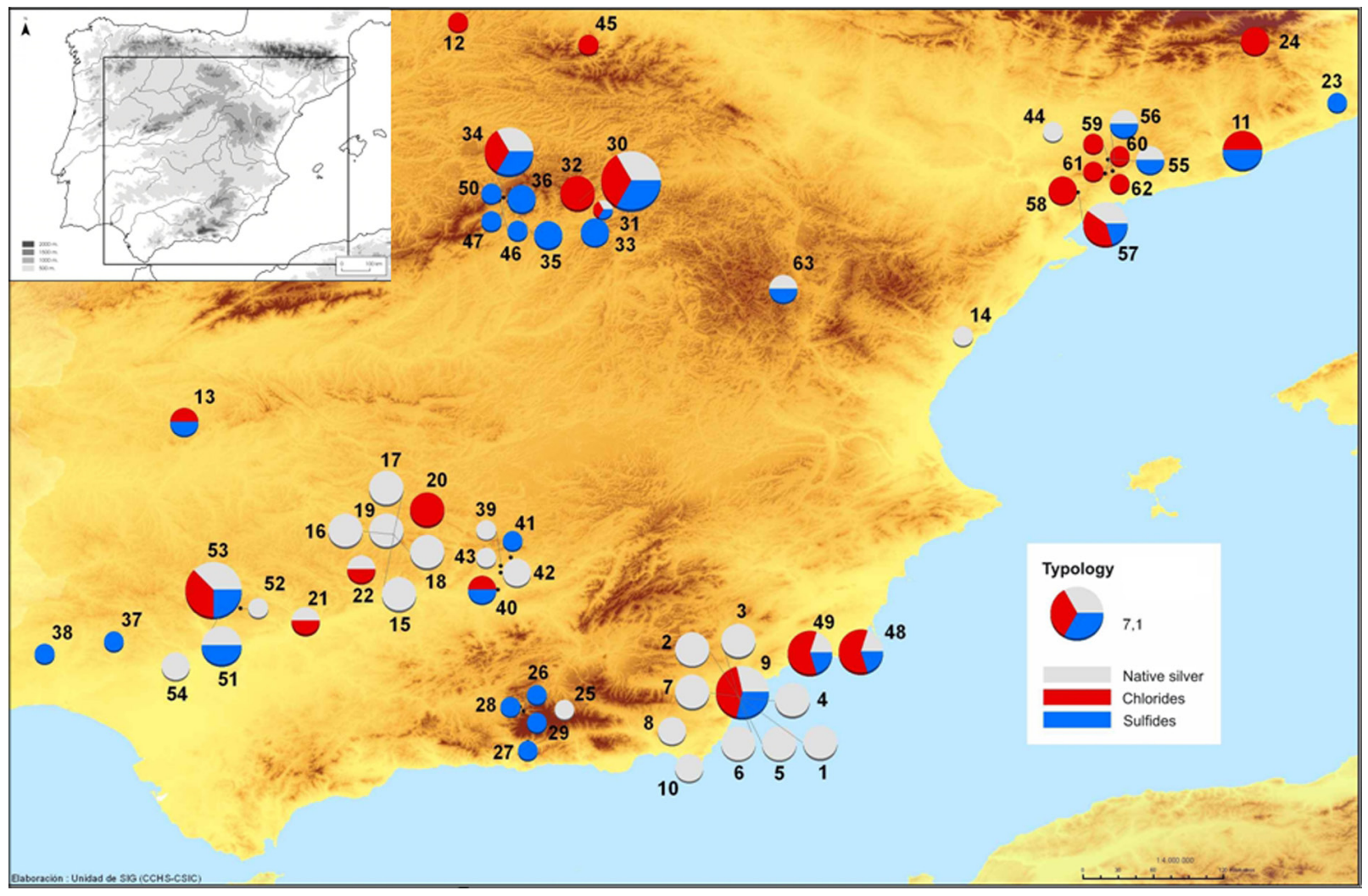

Fig. 5. Map showing the main silver ore deposits of Iberia. Almería: 1-7. Herrerías; 8. Sierra de los Filabres; 9. Barranco del Jaroso, Sierra Almagrera; 10. Cabo de Gata; Barcelona: 11. S. Cugat del Vallés; Burgos: 12. Mansilla; Cáceres: 13. Plasenzuela; Castellón: 14. Mina de la Botalaria, Borriol; Ciudad Real: 15-19. El Horcajo, Valle de Alcudia; 20. Almodóvar del Campo; Córdoba: 21. Casiano del Prado; 22. La Espuela de San Miguel, Villanueva de Córdoba; Girona: 23. Caldes de Malavella; 24. Vall de Ribes; Granada: 25-29. Sierra Nevada; Guadalajara: 30-32. Hiendelaencina; 33. Gajanejos; Madrid: 34-36. Sierra de Guadarrama; Huelva: 37. Río Tinto; 38. Tharsis; Jaén: 39-43. La Carolina-Linares-Santa Elena-El Centenillo; Lleida: 44. Mina Eureka, Torre de Cabdella; Logroño: 45. San Lorenzo; Madrid: 46. Acebeda; 47. Robregordo; Murcia: 48. La Unión, Cartagena; 49. Mina Dolores I y II, Postrana, Mazarrón; Segovia: 50. Prádena; Sevilla: 51. Cazalla de la Sierra; 52. Constantina; 53. Guadalcanal; 54. Gerena; Tarragona: 55. Vimbodí; 56. Espuga de Francolí; 57. Falset; 58. Bellmunt; 59. Farena; 60. Capafonts; 61. Prades; 62. La Selva del Camp; Teruel: 63. Silúrico del Albarracín. 
1971). These minerals could also be used to produce silver, since they are relatively easy to melt (melting point: $960^{\circ} \mathrm{C}$ ) while avoiding the difficulties of cupellation. Native silver also occurs associated with argentite $\left(\mathrm{Ag}_{2} \mathrm{~S}\right)$ and with other lead ores such as galena, cerussite, anglesite or cotunnite (Hunt Ortiz 2005).

The occurrence of native silver is reported and has been mined in modern times at four main deposits in Iberia: Herrerías (Almería), El Horcajo (Ciudad Real) and Hiendelaencina (Guadalajara). In Herrerías (Molina 1991) native silver was documented near the surface where it would have been easily accessible to prehistoric miners. Modern exploitation in Herrerías, beginning in 1992 (Navarro et al. 1999), exposed a new occurrence of native silver with high mercury contents (up to $10 \% \mathrm{wt} \mathrm{Hg}$ ). Some samples contained high levels of cerargyrite disseminated all over the specimen.

Although there are native silver specimens in several museums, compositional analyses of native silver are, up to now, extremely scarce and were carried out only in Herrerías. After the Sirets' analysis of one specimen of Herrerías (Tab. 4), the only analyses performed are those published by us (Tab. 5).

Both, Siret's and our analyses show that the silver is quite pure, with some iron and small concentrations of lead, up to $0.03 \%$. Some copper is also detected, up to $3.14 \%$. However, it is known from catalogues of mineralogical collections (e.g. Valero 1907) and literature references (e.g. López Gómez 1969; Sainz de Baranda et al.
2004) that native silver in Iberia can also occur associated with native copper and as kongsbergite, pyrargyrite or proustite. Therefore, small amounts of $\mathrm{Cu}, \mathrm{Hg}, \mathrm{S}, \mathrm{Sb}$ or As could also be present in silver artefacts.

Native silver in El Horcajo (Ciudad Real) occurs in the shape of massive native silver, capillary over galena, branchy or filamentous in depth, in plates over quartz, and dendritic inside quartzite fissures together with pyromorphite, and it is documented as dendritic masses over goethite, systematically associated with native copper in the 'San Germán Mine' (Sáinz de Baranda et al. 2004). In Hiendelaencina (Guadalajara), native silver occurs as chlorides and bromides close to the surface, and as grey silver or pyrargyrite $\left(\mathrm{Ag}_{3} \mathrm{SbS}_{3}\right)$ and red silver or proustite $\left(\mathrm{Ag}_{3} \mathrm{AsS}_{3}\right)$ in depth (López Gómez 1969).

Moreover, native silver has also been documented in minor quantities in other mining districts in the southeast of Iberia such as Sierra Almagrera (Almería), Sierra de los Filabres (Almería), grey silver and silver associated to chalcopyrite in Sierra Nevada (Granada), Cartagena and Mazarrón (Murcia), Linares or La Carolina (Jaén) (Valero 1907; Calderón 1910; Mesa and Álvarez 1889-1890). In the southwest an important native silver vein was discovered at Guadalcanal (Sevilla), and other minor native silver mines are referenced in Cazalla de la Sierra, Gerena or Constantina (Sevilla), or Villanueva de Córdoba and Casiano del Prado (Córdoba) (Hunt 2005; DGIEM 1986). Further away from the study area, native silver also occurs in Guada-

\begin{tabular}{|c|c|c|c|c|c|c|c|}
\hline $\mathbf{C u}$ & $\mathbf{Z n}$ & $\mathbf{A g}$ & $\mathbf{P b}$ & $\mathbf{F e}$ & As & Se & Others \\
\hline 0.18 & nd & 89.62 & nd & nd & nd & nd & 10.2 (sand, calcium) $\mathrm{Cl}, \mathrm{tr}$ \\
\hline
\end{tabular}

Tab. 4. Results of trace element analysis on a sample of native silver from the oxidation zone of the Herrerías deposit (Almería) by H. and L. Siret (1887) (\% wt).

\begin{tabular}{|c|c|c|c|c|r|c|c|c|c|c|r|}
\hline analysis no. & Cu & Ag & Pb & Fe & Se & Co & Cd & Sn & Te & Au & Hg \\
\hline MA-115835 & 0.94 & 85.6 & 0.05 & 0.27 & $<0.01$ & 0.01 & 0.02 & 0.19 & $<0.01$ & 0.12 & 12.8 \\
MA-115834 & 3.14 & 86.5 & 0.03 & 0.89 & 0.09 & 0.01 & 0.01 & 0.18 & $<0.01$ & 0.11 & 9.1 \\
MA-115833 & 0.08 & 92.1 & 0.02 & 0.44 & 0.03 & 0.02 & 0.05 & 0.16 & $<0.01$ & 0.10 & 7.2 \\
\hline
\end{tabular}

Tab. 5. Results of EDXRF analyses on samples of native silver from the oxidation zone of the Herrerías deposit (Almería). Data are normalized (\% wt). 
rrama (Madrid) (Jordá et al. 2005) or Falset (Tarragona) (Abella 2008) (Fig. 3).

\section{LEAD ISOTOPE ANALYSIS OF SILVER ARTEFACTS AND ORES FROM THE EL ARGAR CULTURE}

The results of lead isotope analyses of the Argaric silver artefacts from Cerro de la Encina and Peñalosa discussed before are presented in table 6 and figure 6 together with those from other Argaric sites such as Cerro de la Virgen, Cuesta del Negro, Pantano de los Bermejales and Terrera del Reloj (all in Granada). Two analyses from La Bastida (Murcia) and San Antón (Alicante) published by Castro et al. 1999 are also plotted. As we can see in figure 6, most of them cluster together (group a), suggesting that they derive from a single source. However, some differences can be detected. On the left side of the 208/206 Pb-207/206 Pb diagram two samples (d and e) are separated from the main group: a massive silver bracelet of 98 gr. from Cuesta del Negro (e) and a silver spiral from Peñalosa (d). The same can be observed on the right side of that diagram with three more samples which form group c (two from Peñalosa, gr. 21 and one from Cuesta del Negro). On the one hand this supports the idea that in those settlements various silver ores were exploited and on the other hand it shows that both sites possibly shared the same silver resources. Moreover, the two samples from Cerro de la Virgen, that from Terrera del Reloj and that from San Antón, which are clustered in group b, are somehow separated from the main group on both diagrams which could indicate the use of different ore sources. The samples from

\begin{tabular}{|c|c|c|c|c|c|c|c|}
\hline Site & Prov. & Type & Analysis n. ${ }^{\circ}$ & Sample n. ${ }^{\circ}$ & $\begin{array}{l}\text { Pb208/ } \\
\text { Pb206 }\end{array}$ & $\begin{array}{l}\text { Pb207/ } \\
\text { Pb206 }\end{array}$ & $\begin{array}{c}\text { Pb206/ } \\
\text { Pb204 }\end{array}$ \\
\hline Cerro de la Encina, gr. 21 & $\mathrm{Gr}$ & Spiral ring & MA-081338 & Mo-39254 & 2.1086 & 0.85844 & 18.188 \\
\hline Cerro de la Encina, gr. 21 & $\mathrm{Gr}$ & al pin & MA-081339 & 9 & 1082 & 85792 & 18.190 \\
\hline Cerro de la Encina, gr. 21 & $\mathrm{Gr}$ & Rivet & MA-081340 & & 083 & 90 & .196 \\
\hline Cerro de la Encina, gr. 21 & $\mathrm{Gr}$ & Spiral ring & MA- & Mo- & 2.1108 & 85856 & 18.171 \\
\hline Cerro de la Encina, gr. 21 & $\mathrm{Gr}$ & Bracelet & MA- & Mo & 2.1082 & .85744 & 18.206 \\
\hline Cerro $\mathrm{C}$ & $\mathrm{Gr}$ & Rivet & MA & Mo- & 2.1079 & 0.85714 & 18.206 \\
\hline la Virgen, gr. 22b & $\mathrm{Gr}$ & Bracelet & $\mathrm{MO}$ & 9807 & 2.1036 & 0.85722 & 18.238 \\
\hline Cerro de la Virgen, gr. 22a & $\mathrm{Gr}$ & Ring & M & 9824 & 2.1041 & 0.85904 & 18.205 \\
\hline Cuesta del Negro, gr. 31 & $\mathrm{Gr}$ & Spiral ring & $\mathrm{N}$ & 9 & 2.1064 & 0.85705 & 18.206 \\
\hline Cuesta del Negro, gr 31 & $\mathrm{Gr}$ & Ring & $\mathrm{MO}$ & 9751 & 2.1069 & 0.85672 & 18.211 \\
\hline Cuesta del Negro, gr. 4 & $\mathrm{Gr}$ & Spiral ring & $\mathrm{N}$ & 1 & 2.1138 & 0.86033 & 18.139 \\
\hline Cuesta del Negro, gr. 4 & $\mathrm{Gr}$ & Ring & $\mathrm{MO}$ & 1 & 2.1088 & 0.85743 & 18.209 \\
\hline Cuesta del Negro, gr 35 & $\mathrm{Gr}$ & $\mathrm{Ri}$ & MO & & 2.0946 & 0.85411 & 18.314 \\
\hline La Bastida & $\mathrm{Mu}$ & Spiral & - & & 2.1095 & 0.85715 & 18.202 \\
\hline $\mathrm{Pa}$ & $\mathrm{Gr}$ & Ring & & & 34 & 0.85803 & 18.185 \\
\hline & $\mathrm{J}$ & $\mathrm{R}$ & 1330 & & & & 18.197 \\
\hline & $\mathrm{J}$ & Spiral & MA & $\mathrm{BE}$ & 2.1072 & 0.8 & 18.202 \\
\hline $\mathrm{Pe}$ & $\mathrm{J}$ & Bracelet & MA & $\mathrm{BE}$ & 2.1068 & 670 & 18.217 \\
\hline gr. 7 & $\mathrm{~J}$ & Bracelet & MA- & BE- & 2.1073 & 0.85749 & 18.200 \\
\hline losa, gr. 21 & $\mathrm{~J}$ & Ring & MA-081334 & BE-42 & 2.1119 & 0.85979 & 18.135 \\
\hline osa, gr. 21 & $\mathrm{~J}$ & Spiral & MA-081336 & BE-42420 & 2.1096 & 0.85833 & 18.175 \\
\hline gr. 21 & $\mathrm{~J}$ & Ring & MA-081337 & BE-42422 & 2.1124 & 0.85997 & 18.135 \\
\hline & $\mathrm{J}$ & Rivet & PA20105 & BE01-09-4 & 2.1040 & 0.85511 & 18.240 \\
\hline & A & Spiral & - & MU 25 & 2.1083 & 0.85879 & 18.218 \\
\hline Terrera del Reloj & $\mathrm{Gr}$ & Ring & MO703 & 13703 & 2.1057 & 0.85859 & 18.202 \\
\hline
\end{tabular}

Tab. 6. Results of lead isotope analyses of silver artefacts from Argaric settlements (gr=grave; Prov= Province; $A=$ Alicante; Gr=Granada; J=Jaén; Mu=Murcia). 

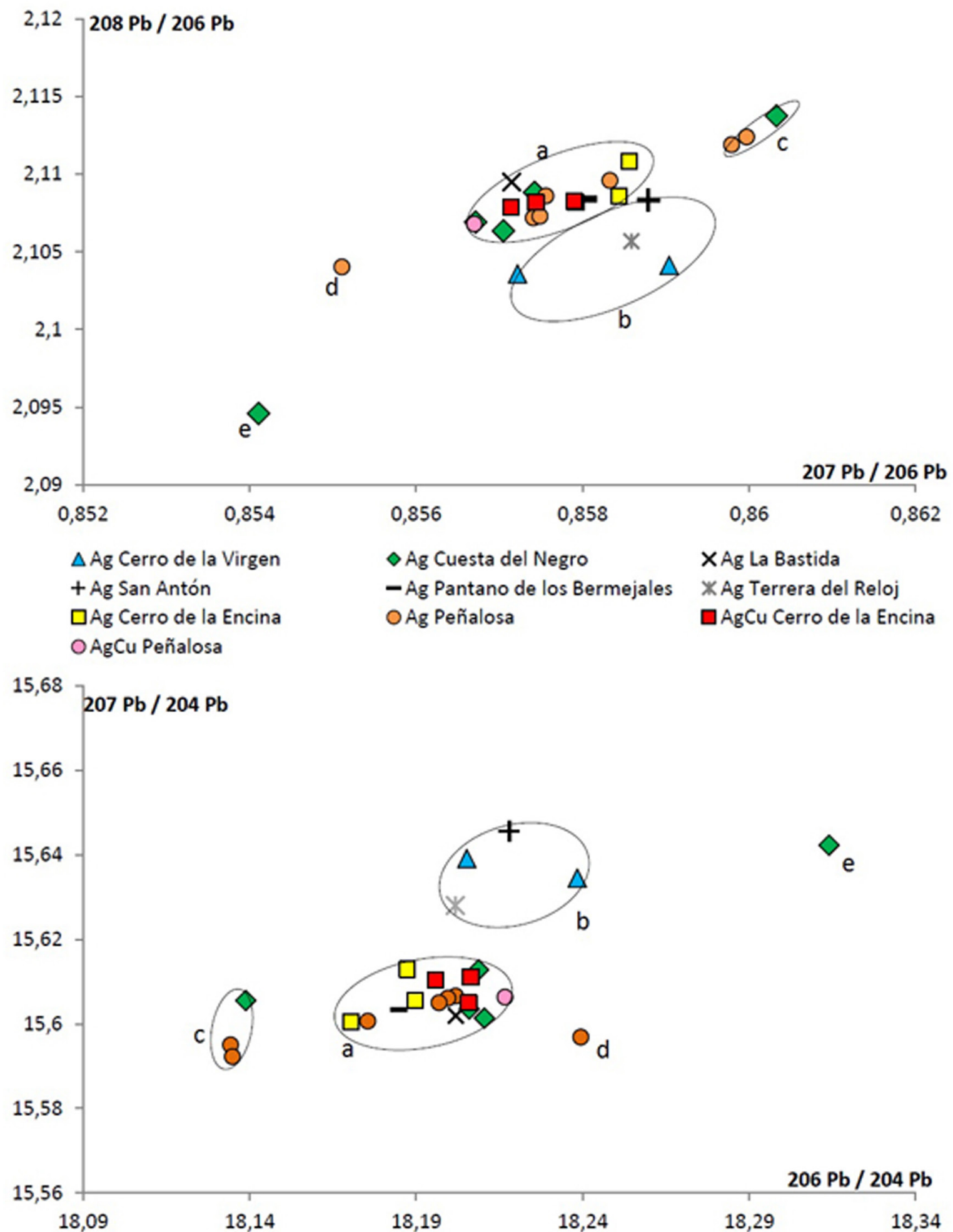

Fig. 6. Lead isotope groups of Argaric silver artefacts (cf. Tab. 5).

Trab. Prehist., 69, N. ${ }^{\circ}$, julio-diciembre 2012, pp. 293-309, ISSN: 0082-5638 doi: $10.3989 /$ tp.2012.12093 
Cerro de la Encina indeed cluster much more together suggesting that probably silver from one single mining area was exploited. However, these samples are from the same grave (no. 21) which might not be representative of the diversity of resources used in that settlement. They fall also coinciding with the data for most of the objects from Peñalosa and Cuesta del Negro as well as the samples from Pantano de los Bermejales and La Bastida. The common clustering of the analysis results of these two sites also in that area supports the assumption that the inhabitants of both settlements could have shared the same ores for exploitation.

Whereas in Cerro de la Encina only few residues of metallurgy were found (Montero 1994: 171; Gómez Ramos 1999: 81), Peñalosa provides abundant evidence. However, this is almost entirely linked to the production of copper for which the whole châine opèratoire has been documented (Contreras 2000; Moreno et al. 2010: 87106). As yet there is no archaeological evidence for the production of silver in Peñalosa.

It is worthwhile to note that the analytical results -trace elements and lead isotope ratios- of objects made of $\mathrm{AgCu}$ alloys plot together with those of pure silver artefacts (Figs. 5-6). This strengthens the idea that the copper was already associated with the native silver or silver chlorides instead of being added to pure silver. An alloy of two metals or minerals would alter both the isotopic signature and the trace element fingerprint of an artefact, unless it originated from the same deposit.

As to the provenance of these objects, their lead isotope ratios were compared with those of published ore samples as well as with those of three samples of native silver and one sample of copper ore from Herrerías analysed by us (Tab. 7) In figure 7 all the isotopic fields of different types of ores from the Iberian southeast are plotted. There are only few lead isotope analyses of deposits with native silver. From the three main mining areas with native silver we only have the three analyses of native silver and one copper ore from Herrerías, two analyses of galena from El Horcajo -while more than 90 analyses of copper and lead ores were published from Valle de Alcudia by Santos Zalduegui et al. (2004) and Klein et al. (2009)- and there is only one analysis of galena from Hiendelaencina (Tornos and Chiarada 2004). From the mines with native silver in smaller quantities we have 35 analyses of copper and lead ores from Linares (Santos Zaldegui et al. 2004; Hunt et al. 2011), 9 from Cartagena, 8 from Mazarrón (Graeser and Friedrich 1970; Stos Gale et al. 1995; Klein et al. 2009), and 9 from Sierra Almagrera (Stos Gale et al. 1995; Dayton and Dayton 1986). All these mining districts are graphically represented in figure 6 together with other mines characterised mainly by copper and lead ores: Gador, Cabo de Gatas, Cerro Minado, Sierra Alhamilla or Sierra Cabrera (Dayton and Dayton 1986; Arribas and Tosdal 1994; Stos Gale et al. 1995; Stos Gale et al. 1999; Tornos and Chiarada 2004; Santos Zalduegui et al. 2004; Klein et al. 2009; Hunt et al. 2011; Montero-Ruiz and Murillo-Barroso 2010). As yet native silver has not been reported anywhere there, but its occurrence in small quantities in prehistory cannot be excluded. There are also some analyses from La Carolina mining district published by Lillo (1992). However, these analyses do not define a cluster isotopic field and have been questioned by Canals and Cardellach (1997) and García de Madinabeitia et al. (2002) therefore they have not been considered in this paper.

We observe that none of the artefacts plot in the area of Herrerías, Sierra Almagrera or the mining districts of the South east. All of them cluster close to the area of the mining districts of Valle de la Alcudia-Linares, in the provinces of Ciudad Real and Jaén. However, most of the objects come from sites in the provinces of Gra-

\begin{tabular}{|l|c|c|c|}
\hline Analysis n. $^{{ }^{0}}$ & Pb208/Pb206 & Pb207/Pb206 & Pb206/Pb204 $^{-0205}$ \\
\hline FG-031129 & 2.0842 & 0.84320 & 18.555 \\
FG-031130 & 2.0753 & 0.83572 & 18.738 \\
FG-031131 & 2.0738 & 0.83516 & 18.758 \\
MO-354 & 2.0806 & 0.83647 & 18.760 \\
\hline
\end{tabular}

Tab. 7. Lead Isotope analyses of native silver (FG-031129-31) and of copper ore (MO-354) from the Herrerías mines (Almería). 


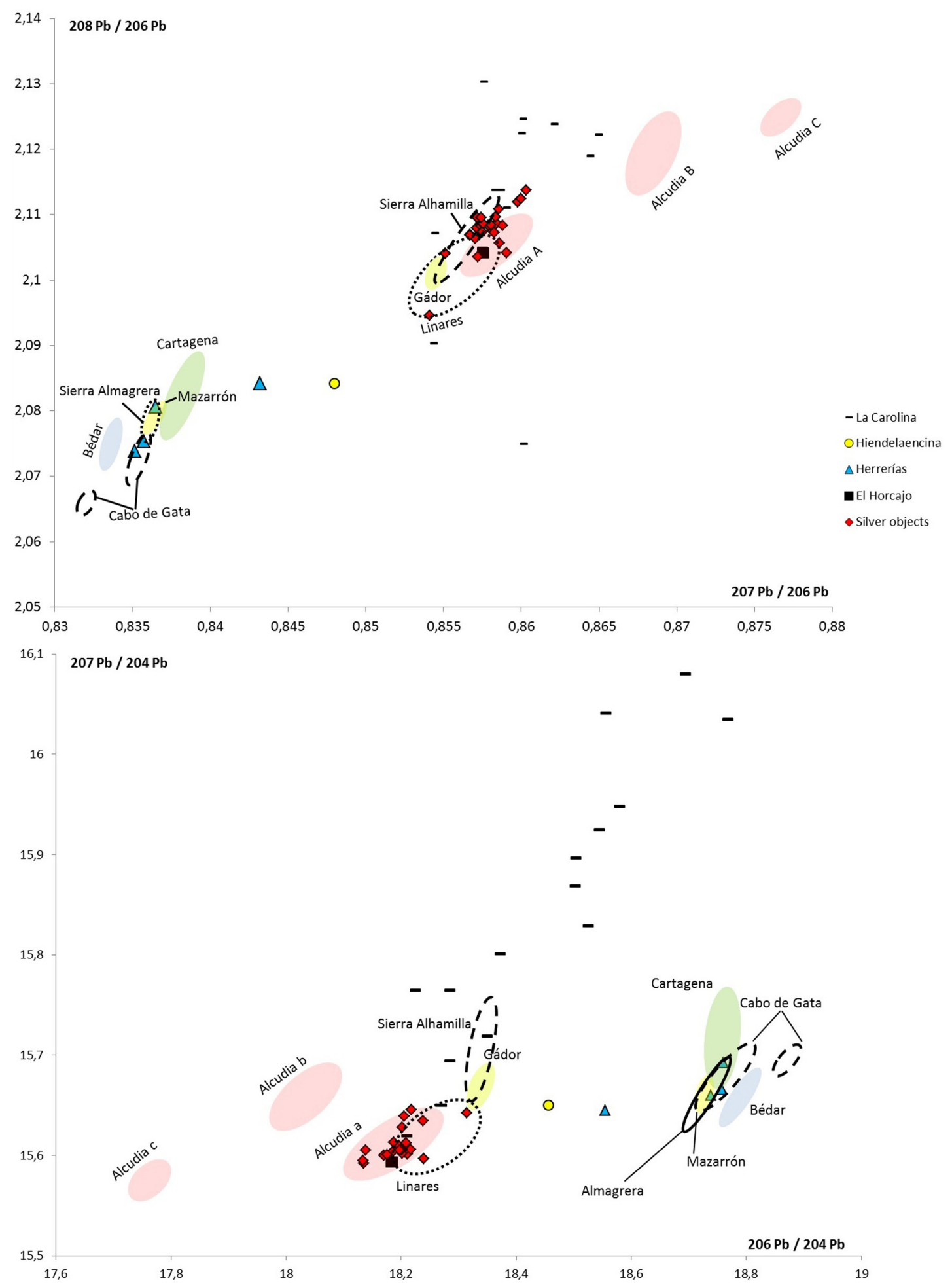

Fig. 7. Lead isotope ratios of Argaric silver artefacts compared to isotopic fields of the main mining districts of Iberian southeast and surroundings, based on 280 published analyses.

Trab. Prehist., 69, N. ${ }^{\circ} 2$, julio-diciembre 2012, pp. 293-309, ISSN: 0082-5638 doi: $10.3989 /$ tp.2012.12093 
nada and Jaén which are closer to those mining districts than to the ones in the South east. The pattern might indeed change when artefacts from sites of Almería or Murcia provinces are analysed in larger quantities.

A look into this area in more detail (Fig. 8) reveals that on the present state of research some provenances can be suggested tentatively. The above mentioned silver spiral from Peñalosa (sample d in Fig. 6), whose lead isotope ratios plot apart from the main group on the left side of the diagram, is located close to those of ores from Linares in all axes, which might point to a provenance of the raw material from there. The geographical proximity of the settlement to the ore district of Linares-Bailén (Santos Zalduegui et al. 2004: Fig. 1; Arboledas et al. 2006; Arboledas and Contreras 2010: Fig. 1) enhances the likeliness of this suggestion. Native silver occurs in the Linares area in minor quantity than in Valle de la Alcudia but chemical analyses of the ores available support the correlation. A similar con- clusion can be drawn for the group of samples from Cerro de la Virgen, Terrera del Reloj and San Antón (group b in Fig. 6) whose lead isotope ratios plot in all axes close to those of ores from the Valle de Alcudia. The bulk of the lead isotope ratios from silver metal samples nevertheless cluster beyond those of the so far isotopically characterised ore districts. Although the values plot close to the isotope fields of the large mining districts of Valle de Alcudia and Linares the systematic scattering above those ratios speaks clearly for a different provenance.

\section{CONCLUSIONS AND OUTLOOK}

The large concentration of more than 700 silver artefacts in the southeast Iberian Bronze Age contrasts significantly with the largely incoherent scatter of silver objects in the rest of prehistoric Europe. As it has been suggested since the $19^{\text {th }}$ century this can be explained by a good acces-

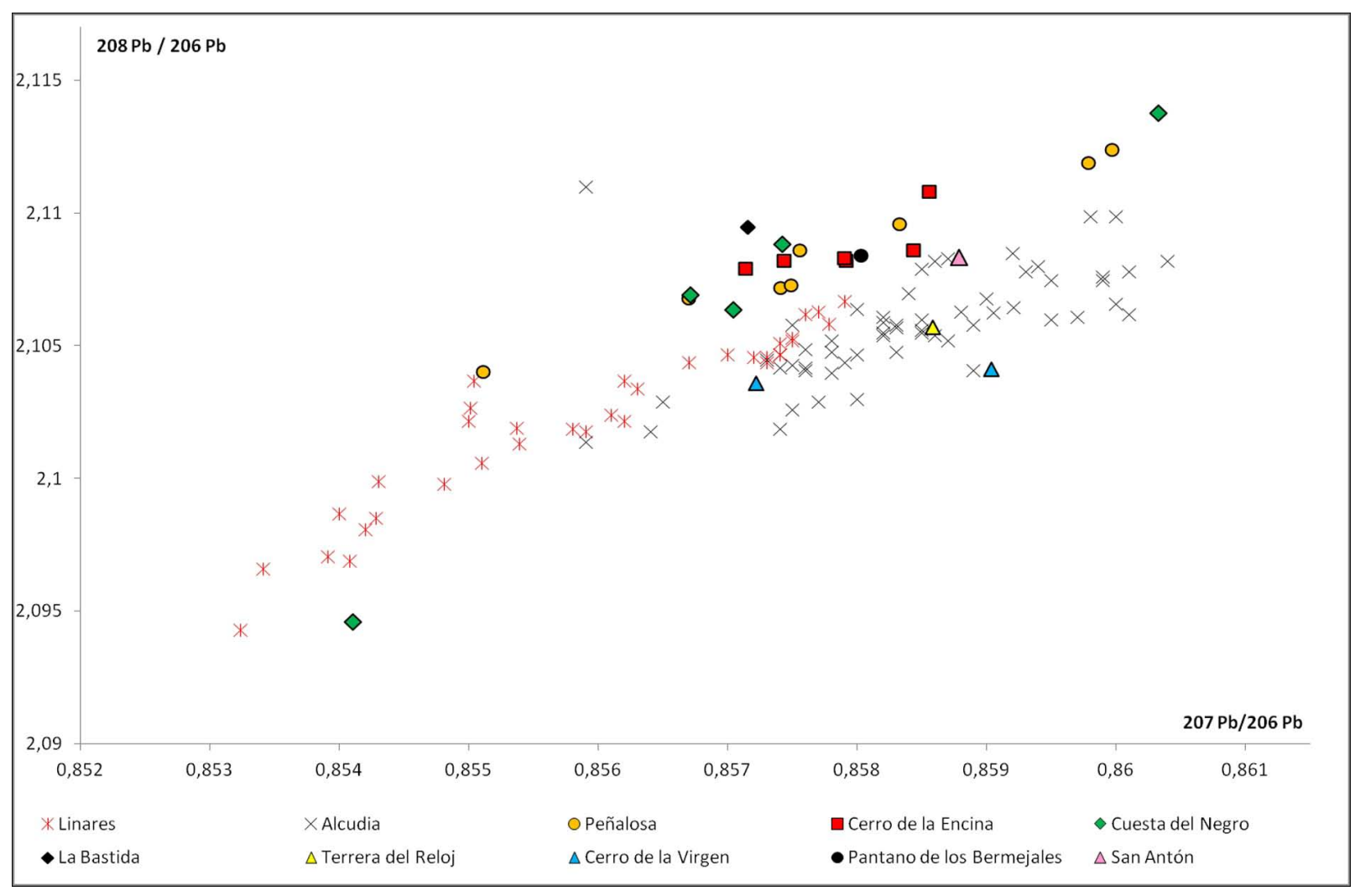

Fig. 8. Lead isotope ratios of Argaric silver artefacts and the closest mining districts. 
sibility of native silver whose use in the Iberian Bronze Age has been proven directly for the first time. Lead isotope analyses show that different sources of silver were exploited, thus it has not been possible to provide convincing evidence for the identification of certain deposits. Apart from a few matches, the bulk of the analysed silver objects do not coincide with any of the lead isotope fingerprints of the known occurrences. Nevertheless, the data available so far speak for a use of silver in Peñalosa, Cerro de la Encina, Pantano de los Bermejales and Cuesta del Negro with a different origin than that found in Cerro de la Virgen, Terrera del Reloj and San Antón. Whether each of these two groups of sites shared the same sources remains unclear. It could also be demonstrated that as yet there is no evidence in Argaric sites in the area of Granada and Jaén for a use of the well known silver deposits in the mining districts of Herrerías and the Iberian Southeast.

As native silver and silver chlorides are often associated with copper their use to produce $\mathrm{AgCu}$ alloys can be proposed in the light of the results presented, as there are no differences in trace elements or isotopic signature between objects with high copper contents and those of pure silver. This is consistent with the results of analyses of cerargyrite beads in Fuente Álamo, with the analyses of native silver from Herrerías which show copper contents up to $2.5 \%$, and with the references to the San Germán mine in El Horcajo, Valle de Alcudia, where native copper occurs systematically associated with native silver. Therefore the use of naturally associated copper and silver seems to be more plausible than the production of intentional alloys.

On the Iberian peninsula a number of deposits with native silver which apparently have been easily accessible in prehistory still lack isotopic characterisation. Mineral deposits in the vicinity of the sites studied by us, e.g. in the provinces of Granada and Málaga, are not yet isotopically characterised, and also for the mining areas in the provinces of Jaén, Almería and Murcia still more analyses are needed to have better defined isotopic fields. Additional chemical and isotopic data are required to document the distribution and extent of the production of silver, the production sites and the distribution of silver objects on the Iberian peninsula. This might in general give clues to the kind and the size of exchange rela- tions during the $2^{\text {nd }}$ millennium $\mathrm{BC}$. Research into the organisation of production and distribution of Bronze Age silver has a high potential to significantly increase our knowledge about exchange systems of that time on the Iberian peninsula and to allow an advanced investigation of the economic structure. The combination of lead isotope and trace element analysis is a powerful tool to investigate especially the presumably comprehensive use of native silver as an important raw material for the production of ornaments in the Iberian Bronze Age.

\section{ACKNOWLEDGMENTS}

This article is part of the projects HAR201130131-CO2-01 La minería en el Alto Guadalquivir. Formas de construcción históricas en la Antigüedad a partir de la producción, consumo y distribución de los metales. Cronología de la consolidación del sedentarismo y la desigualdad social en el Alto Guadalquivir and HAR21105C02-02 Relación entre materias primas locales y producción metalúrgica: Cataluña meridional como modelo de Contraste funded by the Spanish Ministry of Economy and Competitivity. We would like to express our special thanks to Fernando Molina and Gonzalo Aranda (University of Granada) for allowing us to take samples from materials of the site of Cerro de la Encina (Monachil), to Isidro Toro Moyano (director of the Museo Arqueológico Provincial de Granada) for allowing us to take samples from the objects from Cerro de la Encina (Monachil), Cuesta del Negro (Purullena), Cerro de la Virgen (Orce), Terrera del Reloj (Dehesas de Guadix) and Pantano de los Bermejales (Arenas del Rey), to Francisca Hornos (Archaeological Museum of Jaén) for allowing us to take samples from materials of the site of Peñalosa (Baños de la Encina) and to Ignacio Montero (Instituto de Historia, CCHSCSIC, Madrid) for discussing and commenting the results of this study.

\section{BIBLIOGRAPHY}

Abella, J. 2008: Minerals $i$ mines de la Conca de Bellmunt del Priorat. Grup Mineralògic Català-Fons Mineralògic de Catalunya. Sabadell.

Aranda Jiménez, G.; Molina González, F. R.; Fernández Martín, S.; Sánchez Romero, M.; Al Oumaoui,

Trab. Prehist., 69, N. ${ }^{\circ}$ 2, julio-diciembre 2012, pp. 293-309, ISSN: 0082-5638

doi: $10.3989 /$ tp.2012.12093 
I.; Jiménez Brobeil, S. A. and Roca, M. G. 2008: "El poblado y necrópolis argáricos del Cerro de la Encina (Monachil, Granada): las campañas de excavación de 2003-05". Cuadernos de Prehistoria y Arqueología de la Universidad de Granada 18: 219-264.

Arboledas Martínez, L. and Contreras Cortés, F. 2010: "La mina del Polígono o Contraminas (Baños de la Encina, Jaén). Evidencias de la explotación de mineral de cobre en la antigüedad". Cuadernos de Prehistoria y Arqueología de la Universidad de Granada 20: 355-379.

Arboledas Martínez, L.; Contreras Cortés, F.; Moreno Onorato, A.; Dueñas Molina, J. and Pérez Sánchez, A. 2006: "La mina de José Martin Palacios (Baños de la Encina, Jaén). Una aproximación a la minería antigua en la Cuenca del Rumblar". Arqueología y Territorio 3: 179-195.

Arribas Palau, A.; Craddock, P.; Molina, F.; Rothenberg, B. and Hook, D. 1989: "Investigación arqueo-metalúrgica en yacimientos de las Edades del Cobre y del Bronce en el Sudeste de Iberia". In C. Domergue (ed.): Coloquio internacional sobre minería y metalurgia en las antiguas civilizaciones mediterráneas y europeas (Madrid 1985): 71-79. Madrid.

Arribas, A. Jr. and Tosdal, R. M. 1994: "Isotopic composition of $\mathrm{Pb}$ in ore deposits of the Betic Cordillera, Spain: origin and relationship to other European deposit”. Economic Geology 89: 1074-1093.

Bachmann, H. G. 1990: "Zur frühen Blei- und Silbergewinnung in Europa". In H. Steuer and U. Zimmermann (eds.): Montanarchäologie in Europa. Freiburger Forschungen zum ersten Jahrtausend in Südwestdeutschland 4. Jan Thorbecke Verlag. Sigmaringen: 29-36.

Bartelheim, M. 2007: Die Rolle der Metallurgie in vorgeschichtlichen Gesellschaften. Sozioökonomische und kulturhistorische Aspekte der Ressourcennutzung. Ein Vergleich zwischen Andalusien, Zypern und dem Nordalpenraum/The role of metallurgy in prehistoric societies. Socioeconomic and cultural aspects of the use of resources. A comparison between Andalusia, Cyprus and the north Alpine area. Forschungen zur Archäometrie und Altertumswissenschaft 2. Verlag Marie Leidorf GmbH. Rahden, Westfalen.

Briard, J. 1980: "Problèmes métallurgiques du Bronze Armoricain: étain, argent, plomb". In M. Ryan (ed.): The origins of metallurgy in Atlantic Europe. Proceedings of the 5th Atlantic Colloquium (Dublin 1978): 81-96. Dublin.

Calderón, S. 1910: Los minerales de España. Madrid.

Canals, A. and Cardellach, E. 1997: "Ore lead and sulphur isotope pattern from the low-temperature veins of the Catalonian Coastal Ranges (NE Spain)". Mineralium Deposita 32: 243-249.
Castro Martínez, P. V.; Chapman, R.; Gili, S.; Lull, V.; Mico Pérez, R.; Rihuete, C.; Risch, R. and Sanahuja Y11, M. E. 1999: Proyecto Gatas 2. La dinámica arqueoecológica de la ocupación. Consejería de Cultura de la Junta de Andalucía. Sevilla.

Contreras Cortés, F. 2000: Proyecto Peñalosa: análisis histórico de las comunidades de la Edad del Bronce del piedemonte meridional de Sierra Morena y depresión Linares-Bailén. Arqueología, Monografías 10, Sevilla.

Contreras Cortés, F.; Moreno Onorato, A. and Cámara Serrano, J. A. 2010: "Los inicios de la minería. La explotación del mineral del cobre". In F. Contreras Cortés and J. Dueñas Molina (eds.): La minería y la metalurgia en el Alto Guadalquivir: desde sus orígenes hasta nuestros días. Instituto de Estudios Giennenses. Jaén: 43-122.

Dayton, J. E. and Dayton, A. 1986: "Uses and limitations of lead isotopes in archaeology". In J. S. Olin and M. J. Blackman (eds.): Proceedings of the 24th International Archaeometry Symposium (Washington D.C. 1984): 13-41. Washington.

Delibes de Castro, G. and Montero Ruiz, I. 1999: Las primeras etapas metalúrgicas en la Península Ibérica II. Estudios regionales. Instituto Universitario Ortega y Gasset. Madrid.

DGIEM (Dirección General de Industria, Energía y Minas) 1986: Libro Blanco de la Minería Andaluza. Junta de Andalucía. Sevilla.

García de Madinabeitia, S.; Santos Zaldegui, J. F.; Carracedo Sánchez, M.; Larrea Bilbao, F. J. and Gil Ibarguchi, J. I. 2002: "Variaciones en la composición isotópica del $\mathrm{Pb}$ en galenas del área de Los Pedroches: diferencias entre los yacimientos de El Zumajo y Linares-La Carolina”. Geogaceta 32: 239-242.

Gómez Ramos, P. 1999: Obtención de metales en la Prehistoria de la Península Ibérica. British Archaeological Reports, International Series 753, Archaeopress. Oxford.

Graeser, S. and Friedrich, G. 1970: "Zur frage der altersstellung und genese der blei-zink-vorkommen der Sierra de Cartegena in Spanien". Mineralia Deposita 5: 365-374.

Hansen, S. 2009: "Kupfer, Gold und Silber im Schwarzmeerraum während des 5. und 4. Jahrtausends v. Chr.”. In J. Apakidze, B. Govedarica and B. Hänsel (eds.): Der Schwarzmeerraum vom Äneolithikum bis in die Früheisenzeit (5000-500 v. Chr.). Prähistorische Archäologie in Südosteuropa 25,Verlag Marie Leidorf GmbH. Rahden, Westfalen: 11-50.

Harrison, R. J. 1983: "Notas sobre el empleo de la plata en la cultura argárica del SE peninsular". In Homenaje al prof. Martín Almagro Basch 2. Ministerio de Cultura. Madrid: 17-21.

Hartmann, A. 1970: Prähistorische Goldfunde aus Europa. Studien zu den Anfängen der Metallurgie 3, Gebr. Mann Verlag. Berlin. 
Hartmann, A. 1982: Prähistorische Goldfunde aus Europa II. Studien zu den Anfängen der Metallurgie 5, Gebr. Mann Verlag. Berlin.

Hásek, I. 1989: "Die ältesten Gold- und Silberfunde Mitteleuropas". In M. Buchvaldek (ed.): Acta des 14. Internationalen Symposiums Praha-Liblice 1986. Praehistorica 15, Univerzita Karlová. Praha: 49-54.

Hunt Ortiz, M. 1998: "Plata prehistórica: recursos, metalurgia, origen y movilidad". In G. Delibes de Castro (ed.): Minerales y metales en la prehistoria reciente. Algunos testimonios de su explotación y laboreo en la Península Ibérica. Studia Archaeologica 88. Valladolid: 247-289.

Hunt Ortiz, M. 2003: Prehistoric mining and metallurgy in south west Iberian peninsula. British Archaeological Reports, International Series 1188, Archaeopress. Oxford.

Hunt Ortiz, M. 2005: "Plata de Tartessos: producción y dispersión". In S. Celestino Pérez y J. Jiménez Âvila (eds.): El Período Orientalizante. Actas del III Simposio Internacional de Arqueología de Mérida. Protohistoria del Mediterráneo Occidental (Mérida 2003). Anejos de Archivo Español de Arqueología XXXV. Mérida: 1241-1248.

Hunt Ortiz, M.; Contreras Cortés, F. and Arboledas Martínez, L. 2011: "La procedencia de los recursos minerales metálicos en el poblado de la Edad de Bronce de Peñalosa (Baños de la Encina, Jaén). Resultados de análisis de isótopos de plomo". Actas del V Congreso Internacional sobre Minería y Metalurgia Históricas en el Suroeste Europeo (León 2008): 197-208. Madrid.

Jordá Bordehore, L.; Puche Riart, O. and Mazadiego Martínez, L. F. 2005: La minería de los metales y la metalurgia en Madrid. Publicaciones del Instituto Geológico y Minero de España, Serie Recursos Minerales 7. Madrid.

Junghans, S.; Sangmeister, E. and Schröder, M. 1960: Metallanalysen kupferzeitlicher und frühbronzezeitlicher Bodenfunde aus Europa. Studien zu den Anfängen der Metallurgie 1, Gebr. Mann Verlag. Berlin.

Junghans, S.; Sangmeister, E. and Schröder, M. 1968: Kupfer und Bronze in der frühen Metallzeit Europas. Studien zu den Anfängen der Metallurgie 2, 1-3, Gebr. Mann Verlag. Berlin.

Junghans, S.; Sangmeister, E. and Schröder, M. 1974: Kupfer und Bronze in der frühen Metallzeit Europas. Studien zu den Anfängen der Metallurgie 2, 4, Gebr. Mann Verlag. Berlin.

Klein, S.; Domergue, C.; Lahaye, Y.; Brey, G. P. and von Kaenel H. M. 2009: "The lead and copper isotopic composition of copper ores from the Sierra Morena (Spain)". Journal of Iberian Geology 35 (1): 59-68.

Kohlmeyer, K. 1990: "Zur frühen Geschichte von Blei und Silber”. In R. B. Wartke (ed.): Handwerk und
Technologie im Alten Orient. Staatliche Museen zu Berlin. Berlin: 41-48.

Leskov, A. M. 2008: The Maikop Treasure. University of Pennsylvania Museum of Archaeology and Anthroplogy. Philadelphia.

Lillo, J. 1992: "Vein-type base-metal ores in LinaresLa Carolina (Spain): ore-lead isotopic constrains". European Journal of Mineralogy 4: 337-343.

López Gómez, A. 1969: "El Distrito Minero de Hiendelaencina. Guadalajara". Cuadernos de Geografía 6: $211-250$.

Makkay, J. 1991: "The most ancient gold and silver in central and south-east Europe". In J. P. Mohen and C. Eluère (eds.): Découverte du Métal. Picard. Paris: 119-129.

Mesa y Álvarez, P. de 1889-1890: "Memoria sobre la zona minera Linares-La Carolina". Revista minera, metalúrgica y de ingeniería XL y XLI, agosto de 1889 a diciembre de 1890 .

Molina Sánchez, A. 1991: Cuevas: la tierra de la plata. Ayuntamiento de Cuevas de Almanzora. Almería.

Montero Ruiz, I. 1994: El origen de la metalurgia en el sudeste de la Península Ibérica. Instituto de Estudios Almerienses. Almería.

Montero Ruiz, I. and Murillo-Barroso, M. 2010: "La producción metalúrgica en las sociedades argáricas y sus implicaciones sociales: una propuesta de investigación". Menga 1: 37-52.

Montero Ruiz, I.; Rovira Llorens, S. and Gómez-Ramos, P. 1995: "Plata argárica". Boletín de la Asociación Española de Amigos de la Arqueología 35: 97-106.

Moreno Onorato, A.; Contreras Cortés, F.; Renzi, M.; Rovira Llorens, S. and Cortés Santiago, H. 2010: "Estudio preliminar de las escorias y escorificaciones del yacimiento metalúrgico de la Edad del Bronce de Peñalosa (Baños de la Encina, Jaén)". Trabajos de Prehistoria 67 (2): 305-322.

Navarro Flores, A.; Collado Fernández, D. M. and Sánchez Garrido, J. A. 1999: "Contaminación del suelo por actividades mineras en el entorno del área minera de Sierra Almagrera: características generales y mecanismos de movilidad". In A. Navarro Flores, J. A. Sánchez Garrido and D. M. Collado Fernández (eds.): Minería, Industria y Medio Ambiente en la Cuenca Mediterránea. Universidad de Almería. Almería.

Patterson, C. C. 1971: "Native copper, silver and gold accessible to early metallurgists". American Antiquity 36 (3): 286-321.

Perea, A. 1991: Orfebrería prerromana. Arqueología del oro. Caja de Madrid. Madrid.

Perea, A.; García Vuelta, Ó. and Fernández Freire, F. 2010: El Proyecto Au. Estudio arqueométrico de la producción de oro en la Península Ibérica. Bibliotheca Praehistorica Hispana XXVII. Consejo Superior de Investigaciones Científicas. Madrid. 
Pérez Macías, J. A. 1996: Metalurgia extractiva prerromana en Huelva. Universidad de Huelva. Huelva.

Pérez Macías, J. A. and Frías, C. 1989: "La necrópolis de cistas de La Parrita (Nerva, Huelva) y los inicios de la metalurgia de la plata en las minas de Río Tinto". Cuadernos del Suroeste 1: 11-21.

Pernicka, E. 1987: "Erzlagerstätten in der Ägäis und ihre Ausbeutung im Altertum. Geochemische Untersuchungen zur Herkunftsbestimmung archäologischer Metallobjekte". Jahrbuch des RömischGermanischen Zentralmuseums 34: 607-714.

Pernicka, E. 1990: "Gewinnung und Verbreitung der Metalle in prähistorischer Zeit". Jahrbuch des R̈̈misch-Germanischen Zentralmuseums 37: 21-129.

Pernicka, E. and Bachmann, H.-G. 1983: "Archäometallurgische Untersuchungen zur antiken Silbergewinnung in Laurion. Teil III". Erzmetall 36: 592-597.

Pingel, V. 1992: Die vorgeschichtlichen Goldfunde der Iberischen Halbinsel: eine archäologische Untersuchung zur Auswertung der Spektralanalysen. Madrider Forschungen 17, Walter de Gruyter. Berlin, New York.

Pingel, V.; Schubart, H.; Arteaga, O.; Roos, A. M. and Kunst, M. 2003: "Excavaciones arqueológicas en la ladera sur de Fuente Álamo". SPAL 12: 179-230.

Pozo, M.; Medina, J. A. and Casas, J. 2004: “Caracterización mineralógica de cuentas de ajuar procedentes de tres tumbas de Fuente Álamo". Madrider Mitteilungen 45: 108-131.

Prag, K. 1978: "Silver in the Levant in the Fourth Millennium BC". In R. Moorey (ed.): Archaeology in the Levant. Essays for Kathleen Kenyon. Aris and Phillips. Warminster: 36-45.

Primas, M. 1995: "Gold and silver during the 3rd mill. cal. BC". In G. Morteani and J. P. Northover (eds.): Prehistoric Gold in Europe. Dordrecht. Boston-London: 77-93.

Primas, M. 1996: "Frühes Silber”. In T. Kovács (ed.): Studien zur Metallindustrie im Karpatenbecken und den benachbarten Regionen. Magyar Nemzeti Múzeum. Budapest: 55-58.

Renfrew, C. 1967: "Cycladic Metallurgy and the Aegean Early Bronze Age". American Journal of Archaeology 71: 1-20.

Rothenberg, B. and Blanco Frejeiro, A. 1981: Studies in Ancient Mining and Metallurgy in South-West
Spain. Explorations and Excavations in the Province of Huelva. Metals in History 1, Thames \& Hudson. London.

Rovira, S.; Montero, S. and Consuegra, S. 1997: Las primeras etapas metalúrgicas en la Península Iberica. I Análisis de materiales. Instituto Universitario Ortega y Gasset. Madrid.

Sainz de Baranda, B.; Palero, F. J. and García, G. 2004: "El Horcajo. Las Piromorfitas más famosas del mundo". Cuaderno de Campo: 30-69.

Santos Zalduegui, J. F.; García de Madinabeitia, S.; Gil Ibarguchi, J. I. and Palero, F. 2004: "A lead istope database: The Los Pedroches-Alcudia Area (Spain); Implications for Archaeometallurgical connections across southwestern and southeastern Iberia". Archaeometry 46 (4): 625-634.

Simón García, J. L. 1998: La metalurgia prehistórica valenciana. Servicio de Investigación Prehistórica, Serie de Trabajos Varios 93. Valencia.

Siret, H. and L. 1887: Les premiers âges du métal dans le sud-est de l'Espagne. Museum Vleeshuis. Antwerpen.

Stos-Gale, Z. A.; Gale, N. H.; Houghton, J.; Speakman, R. 1995: "Lead Isotope data from the Isotrace Laboratory, Oxford: Archaeometry Data Base 1, Ores from the Western Mediterranea". Archaeometry 37 (2): 407-415.

Stos-Gale, S.; Hunt Ortiz, M. and Gale, N. 1999: "Análisis elemental y de isótopos de plomo de objetos metálicos de los sondeos de Gatas". In P. Castro, R. Chapman, S. Gili, V. Lull, R. Micó, C. Rihuete, R. Risch and M. E. Sanahuja Yll (eds.): Proyecto Gatas 2. La dinámica arqueoecológica de la ocupación prehistórica. Consejería de Cultura de la Junta de Andalucía. Sevilla: 347-361.

Tornos, R. and Chiarada, M. 2004: "Plumbotectonic Evolution of the Ossa Morena Zone: Iberian Peninsula: Tracing the Influence of Mantle-Crust Interaction in Ore-Forming Processes". Economic Geology 99: 965-985.

Tylecote, R. F. 1987: The Early History of Metallurgy in Europe. Longman. London, New York.

Valero, I. 1907: "Minerales Españoles de la Colección del Colegio del Salvador". Boletín de la Sociedad Aragonesa de Ciencias Naturales 7: 62-85.

Wagner, G. A. and Weisgerber, G. 1985: Silber, Blei und Gold auf Sifnos, prähistorische und antike Metallproduktion. Der Anschnitt 3, Deutsches Bergbau-Museum Bochum. Bochum. 